\title{
Growth of Haematococcus pluvialis Flotow in alternative media
}

\author{
L. H. Sipaúba-Tavares ${ }^{*}$, F. A. Berchielli-Morais ${ }^{a}$ and B. Scardoeli-Truzzi ${ }^{a}$ \\ aLimnology and Plankton Production Laboratory, Aquaculture Center, Universidade Estadual Paulista "Júlio de Mesquita \\ Filho" - UNESP, Via de Acesso Prof. Paulo D. Castellane, s/n, CEP 14884-900, Jaboticabal, SP, Brazil \\ *e-mail: sipauba@caunesp.unesp.br
}

Received: December 10, 2013 - Accepted: May 22, 2014 - Distributed: November 30, 2015

(With 3 figures)

\begin{abstract}
Current study investigates the effect of two alternative media: NPK (20-5-20) fertilizer and NPK plus macrophyte $(\mathrm{M}+\mathrm{NPK})$ compared to the commercial medium (WC) under growth rate and physiological parameters in batch culture mode (2-L), and verifies whether the use of fertilizer (NPK) and macrophyte (Eichhornia crassipes) would be a good tool for Haematococcus pluvialis culture in the laboratory. The highest number of cells of $H$. pluvialis has been reported in NPK medium $\left(5.4 \times 10^{5}\right.$ cells. $\left.\mathrm{mL}^{-1}\right)$ on the $28^{\text {th }}$ day, and in the M+NPK and WC media $\left(4.1 \times 10^{5} \mathrm{cells}^{\mathrm{mL}} \mathrm{mL}^{-1}\right.$ and $2.1 \times 10^{5}$ cells. $\left.\mathrm{mL}^{-1}\right)$ on the $26^{\text {th }}$ day, respectively. Chlorophyll- $a$ contents were significantly higher $(\mathrm{p}<0.05)$ in NPK medium (41-102 $\left.\mu \mathrm{g} . \mathrm{L}^{-1}\right)$ and lower in WC and M+NPK media (14-61 $\left.\mu \mathrm{g} . \mathrm{L}^{-1}\right)$. The astaxanthin content was less than $0.04 \mathrm{mg} . \mathrm{L}^{-1}$. Production cost of 10-L of $H$. pluvialis was low in all media, and NPK and M+NPK media had a cost reduction of $65 \%$ and $82 \%$, respectively when compared with commercial medium (WC). The use of a medium based on commercial fertilizer and macrophyte (E. crassipes) produced a new medium formulation that proved to be efficient, at least in batch culture mode, in promoting high density culture of $H$. pluvialis. NPK and macrophyte (E. crassipes) medium seems to be an adequate alternative to replace the conventional one (WC).
\end{abstract}

Keywords: microalgae, NPK (20-5-20), Eichhornia crassipes, biochemical composition, economic aspects.

\section{Crescimento de Haematococcus pluvialis Flotow em meios alternativos}

\section{Resumo}

O presente estudo investigou o efeito de dois meios alternativos, NPK (20-5-20) e NPK mais macrófita (M+NPK), em relação ao meio comercial (WC) para avaliar a taxa de crescimento e parâmetros fisiológicos em cultivo estático (2-L), a fim de verificar se o fertilizante (NPK) e a macrófita (Eichhornia crassipes) podem ser utilizados no cultivo de Haematococcus pluvialis em laboratório. O maior número de células de H. pluvialis foi observado no meio NPK $\left(5,4 \times 10^{5}\right.$ células. $\left.\mathrm{mL}^{-1}\right)$ no vigésimo oitavo dia, e nos meios $\mathrm{M}+\mathrm{NPK}$ e WC foi de $4,1 \times 10^{5}$ células. $\mathrm{mL}^{-1} \mathrm{e}$ $2,1 \times 10^{5}$ celulas. $\mathrm{mL}^{-1}$ no vigésimo sexto dia, respectivamente. Os teores de clorofila- $a$ foram significativamente maiores $(\mathrm{p}<0,05)$ em meio NPK (41-102 g. $\left.\mathrm{L}^{-1}\right)$ quando comparado aos meios WC e M+NPK (14-61 g.L $\left.\mathrm{L}^{-1}\right)$. O teor de astaxantina foi menor que $0,04 \mathrm{mg} . \mathrm{L}^{-1}$. O custo de produção de 10 -L de H. pluvialis foi baixo em todos os meios sendo que os meios NPK e M+NPK apresentaram uma redução de custos de $65 \%$ e $82 \%$, respectivamente, quando comparados ao meio comercial. O meio contendo fertilizante e o de macrófita (E. crassipes) obtiveram resultados eficientes em cultivo estático, com alta densidade celular de H. pluvialis. O meio NPK e o de macrófita (E. crassipes) demonstraram ser uma alternativa adequada para substituir o meio comercial (WC).

Palavras-chave: microalga, NPK (20-5-20), Eichhornia crassipes, composição bioquímica, aspectos econômicos.

\section{Introduction}

The growing demand for microalgae and the high cost of chemical synthesis have encouraged research on production from other alternative media. The greatest interest to all involved in algae culture is maximizing production and minimizing costs.

A common approach to determine the factors for optimal biomass production is to start from a known medium and associate it with other elements that optimize microalgae's growth and nutritive value (Dalay et al., 2007).
Inorganic fertilizers are simple since they are widely available, dissolve easily, feature a defined composition, high nitrogen and phosphorus rate, and trigger moderate $\mathrm{pH}$ in the medium (Tew et al., 2006). In aquaculture, the aquatic floating macrophyte Eichhornia crassipes takes up inorganic nutrients from the water, mainly nitrogen and phosphorus, by the roots and stores them in its biomass. Associated with inorganic fertilizers such as NPK, it results 
in an efficient alternative medium to Chlorophyceae algae (Sipaúba-Tavares et al., 2009).

Complex B vitamins (thiamine, cobalamin and biotin) are essential for most microalgae since vitamin $B_{12}$ is needed by approximately $70 \%$ of microalgae (Hoff and Snell, 1997). Vitamins have been reported to be another important component since they increase the productivity of vegetative Haematococcus cultures. However, no comprehensive study has been performed to find out the optimum levels of vitamins in batch cultures mode (Göksan et al., 2011).

The unicellular green algae Haematococcus pluvialis Flotow (Chlorophyceae) has a complex life cycle which transforms resting eggs or cysts (that are enlarged cells) and accumulates large amounts of carotenoids, especially astaxanthin. The cultivation of $H$. pluvialis is problematic due to its slow growth rate, low cell concentration and susceptibility to contamination (Göksan et al., 2011). The optimization of culture medium and conditions of laboratory are necessary to support higher cell numbers and no contaminations.

The need to improve the cultivation of microalgae for nutritional fish larvae, pigment in aquaculture and a supplementary addition in the food industry have triggered many practical studies in different fields. Alternative medium should allow efficient production of microalgae at low costs in the laboratory (Sipaúba-Tavares and Pereira, 2008).

Light and nitrogen are the two most effective factors that influence microalgae growth, whilst ammonium is the most preferred nitrogen source of microalgae. It is also the most energetically efficient source, since less energy is required for its uptake (Perez-Garcia et al., 2011). In $H$. pluvialis culture, the deficiency of a nutrient, such as nitrogen, induces encystment, with a morphological change from vegetative to cysts cells as the resting stage (Dalay et al., 2007).

Almost all previous studies focused on the growth of H. pluvialis or any other kind of microalgae which provides nutrients for growth by using a commercial medium or fertilizer but not an aquatic plant (Eichhornia crassipes) extract with another source of nutrients.

Current study investigates the effect of an alternative medium, NPK (20-5-20) fertilizer and NPK plus macrophyte $(\mathrm{M}+\mathrm{NPK})$, and the commercial medium (WC) for growth rate and physiological parameters in batch culture mode (2-L), and verifies whether the use of fertilizer (NPK) and macrophyte (Eichhornia crassipes) extract will be a good tool for $H$. pluvialis culture in the laboratory. Results will show whether physiological differences exist between commercial medium and the alternative media, and which medium improves the growth and biochemical composition of $H$. pluvialis.

\section{Material and Methods}

\subsection{Microalga strain and culture conditions}

Haematococcus pluvialis (CMEA $227 \mathrm{C} 1$ ) was obtained from the culture collection of the Biology Department of the Federal University of Rio de Janeiro, Rio de Janeiro, Brazil. So that the effects of different media on the growth of $H$. pluvialis could be examined, three culture media were employed: a commercial WC medium (Guillard and Lorenzen, 1972) and two alternative media, or rather, one with the fertilizer NPK (20-5-20) (Sipaúba-Tavares and Rocha, 1993) and another medium with a mixture of macrophyte (Eichhornia crassipes) extract and NPK fertilizer (M+NPK) (Table 1). The latter contained approximately $5 \mathrm{~kg}$ of Eichhornia crassipes, ground and boiled in distilled water for one hour (Sipaúba-Tavares et al., 2009). Media were used for the maintenance of cultures and the experiments were undertaken in 2-L volume, with continuous air bubbles, at $23 \pm 2{ }^{\circ} \mathrm{C}$. Vitamin B complex was added to the alternative medium at the rate of $0.02 \mathrm{~g} . \mathrm{L}^{-1}$, plus vitamin H. Continuous illumination was applied at an average

Table 1. Nutrients composition of different culture media: NPK; WC and M+NPK.

\begin{tabular}{|c|c|c|c|}
\hline Constituents & $\begin{array}{l}\text { NPK } \\
(\mathrm{g} / \mathrm{L})\end{array}$ & WC $(g / L)$ & $\begin{array}{c}* \mathbf{M}+\mathbf{N P K} \\
(\mathrm{g} / \mathrm{L})\end{array}$ \\
\hline $\mathrm{P}_{2} \mathrm{O}_{5}$ & 2.5 & - & - \\
\hline $\mathrm{K}_{2} \mathrm{O}$ & 10 & - & - \\
\hline $\mathrm{N}$ & 10 & - & 0.095 \\
\hline $\mathrm{P}$ & - & - & 0.091 \\
\hline $\mathrm{C}$ & - & - & 0.199 \\
\hline $\mathrm{Mn}$ & - & - & 0.06 \\
\hline $\mathrm{Mg}$ & - & - & 0.003 \\
\hline $\mathrm{Fe}$ & - & - & 2.13 \\
\hline K & - & - & 0.056 \\
\hline $\mathrm{Ca}$ & - & - & 0.001 \\
\hline $\mathrm{Cu}$ & - & - & $0.05 \mathrm{mg}$ \\
\hline NaEDTA & - & 0.004 & - \\
\hline $\mathrm{KH}_{2} \mathrm{PO}_{4}$ & - & 0.005 & - \\
\hline Trisaminomethane & - & $0.115 \mathrm{mg}$ & - \\
\hline Thiamine $\left(\mathrm{B}_{1}\right)$ & 0.007 & $100 \mu \mathrm{g}$ & 0.007 \\
\hline Vit $\mathrm{B}_{2}$ & 0.007 & - & 0.007 \\
\hline Vit $B_{6}$ & 0.005 & $0.5 \mu \mathrm{g}$ & 0.005 \\
\hline Vit $B_{12}$ & $33 \mu \mathrm{g}$ & - & $33 \mu \mathrm{g}$ \\
\hline Vit H & $0.01 \mathrm{mg}$ & - & $0.01 \mathrm{mg}$ \\
\hline $\mathrm{NaNO}_{3}$ & - & 0.042 & - \\
\hline $\mathrm{FeCl}_{3} 6 \mathrm{H}_{2} \mathrm{O}$ & - & 0.031 & - \\
\hline $\mathrm{CaCl}_{2 .} 6 \mathrm{H}_{2} \mathrm{O}$ & - & 0.036 & - \\
\hline $\mathrm{MnCl}_{2 .} 4 \mathrm{H}_{2} \mathrm{O}$ & - & $0.018 \mathrm{mg}$ & - \\
\hline $\mathrm{CuSO}_{4} .5 \mathrm{H}_{2} \mathrm{O}$ & - & $10 \mu \mathrm{g}$ & - \\
\hline $\mathrm{ZnCl}_{2}$ & - & $22 \mu \mathrm{g}$ & - \\
\hline $\mathrm{Na}_{2} \mathrm{MoO}_{4} 2 \mathrm{H}_{2} \mathrm{O}$ & - & $6 \mu \mathrm{g}$ & - \\
\hline $\mathrm{H}_{3} \mathrm{BO}_{3}$ & - & 0.001 & - \\
\hline $\mathrm{NaHCO}_{3}$ & - & 0.012 & - \\
\hline $\mathrm{MgSO}_{4} 7 \mathrm{H}_{2} \mathrm{O}$ & - & 0.037 & - \\
\hline $\mathrm{CoCl}_{2} \cdot 2 \mathrm{H}_{2} \mathrm{O}$ & - & $10 \mu \mathrm{g}$ & - \\
\hline
\end{tabular}

*The Composition of macrophyte extract (E. crassipes) plus NPK fertilizer was based according Sipaúba-Tavares et al. (2009). 
light intensity of $20 \mu \mathrm{mol} . \mathrm{m}^{2} . \mathrm{s}^{-1}$. Light was provided by cool white fluorescent lamps to observe the transformation from vegetative cells to cysts $\left(60 \mu \mathrm{mol} . \mathrm{m}^{2} . \mathrm{s}^{-1}\right)$. Only the green cells from the exponential growth phase were used as inoculum for the experiment.

\subsection{Culture experiment}

Experiments were maintained in batch culture mode and the culture parameters periodically measured for 28 days. The experiment started with $250 \mathrm{~mL}$ flasks, density $0.40 \times 10^{5}$ cells. $\mathrm{mL}^{-1}$, containing WC medium. When cultures reached the late exponential growth phase ( 7 days), about $200 \mathrm{~mL}$, density $0.13 \times 10^{5}$ cells. $\mathrm{mL}^{-1}$, was added 2-L, containing WC medium. After the 7-day exponential growth phase, the culture, density $0.26 \times 10^{5}$ cells. $\mathrm{mL}^{-1}$, was transferred to other 2-L sterilized recipients containing the three different media (WC; NPK; M+NPK). The samples to growth rate, others physiological parameters and analytical method were analyzed weekly $(1,7,14,21$ and 28 days) during the study period.

\subsection{Growth}

Cell growth was monitored over a period of 28-days. Triplicate $1 \mathrm{~mL}$ aliquots were removed daily from the microalgae culture and a minimum of $2 \times 1 \mu \mathrm{L}$ sub-sample was used for cell quantification with a Neubauer hemocytometer. Growth rate $\mathrm{k}$ (divisions per day) was calculated by the formula: $\mathrm{k}=\left(3.322 / \mathrm{t}_{2}-\mathrm{t}_{1} \times \log \mathrm{N}_{2} / \mathrm{N}_{1}\right)(\mathrm{t}=$ time; $\mathrm{N}=$ number of cells. Subscripts denote rates at different times) (Guillard, 1973). Doubling time (cell division time or generation time) was calculated from results obtained from the growth rate by the formula: $\mathrm{Td}=1 \mathrm{k}^{-1}\left(\mathrm{Td}=\right.$ duplication time; $1 \mathrm{k}^{-1}=$ days per division) (Guillard, 1973). Dry weight and ash content were determined following Vollenweider(1974). The total length of 50 specimens was determined with microscope Leica DFC 295 by image analysis system Las Core (LAS V3.8) with a $40 \times$ micrometric objective. Cell volume was calculated by mean cell size with the most appropriate geometric form, corresponding to the sphere formula (Hillebrand et al., 1999). Total organic carbon (TOC) was calculated by $\mathrm{C}=0.1204$. $\mathrm{V}^{1.051}\left(\mathrm{C}=\right.$ carbon content in pg.cell ${ }^{-1} ; \mathrm{V}=$ cell volume $)$ using regression, according to Rocha and Duncan (1985).

\subsection{Analytical methods}

Nitrate, ammonia, nitrite, orthophosphate and total phosphorus in the culture were evaluated and quantified spectrophotometrically according to techniques described by Golterman et al. (1978) and Koroleff (1976). Chlorophyll- $a$ was extracted with $90 \%$ alcohol and quantified at 663 and $750 \mathrm{~nm}$ (Nusch, 1980). Further, pH, conductivity, temperature and dissolved oxygen were measured with a multiparameter probe YSI 556 MPS. The biomass of the microalgae was harvested, centrifuged and lyophilized for the analysis of proteins and lipids (AOAC, 1990). Astaxanthin was quantified on the $28^{\text {th }}$ day and extracted with petroleum ether and quantified spectrophotometrically at $470 \mathrm{~nm}$ (Carvalho et al., 1992).

\subsection{Analysis of culture medium costs}

The medium's cost of production includes the prices of vitamin B complex, NPK fertilizer and different row materials in the commercial medium (WC). Cost of the macrophyte was discarded and the plants were harvested at different sites of the University campus. The economic aspects have been analyzed with 10-L of culture medium production.

\subsection{Statistical analysis}

All experiments were carried out in triplicate. One-way ANOVA was applied for simple verification between the media (Fowler et al., 1998). Differences were significance at $5 \%$ probability $(\mathrm{p} \leq 0.05)$. Statistical analyses were performed with Statistica 8.0 (Statsoft Inc., 2007).

\section{Results}

The effects of three different conditions on the growth of $H$. pluvialis were simultaneously investigated during a 28-day cultivation period. Experiments were performed under the same growth conditions.

Figure 1 shows that there were significant differences with regard to the growth of cells starting from 5 days up to 13 days of the cultivation period in different culture media at a light intensity of $20 \mu \mathrm{mol} . \mathrm{m}^{2} . \mathrm{s}^{-1}$. Cell concentration during this period reached the maximum value $1.5 \times 10^{5}$ cells. $\mathrm{mL}^{-1}$ in M+NPK culture medium on the $11^{\text {th }}$ and $13^{\text {th }}$ days of cultivation, after which it decreased slightly. On the other hand, cell concentrations in WC and NPK culture media were lower, ranging between $0.4 \times 10^{5}$ cells. $\mathrm{mL}^{-1}$ and $1.08 \times 10^{5}$ cells. $\mathrm{mL}^{-1}$ and between $0.55 \times 10^{5}$ cells. $\mathrm{mL}^{-1}$ and $1.5 \times 10^{5}$ cells. $\mathrm{mL}^{-1}$, on the $5^{\text {th }}$ day and $13^{\text {th }}$ day, respectively. Cell growth between the $17^{\text {th }}$ and the $20^{\text {th }}$ day of the cultivation period at light intensity of $20 \mu \mathrm{mol} . \mathrm{m}^{2} . \mathrm{s}^{-1}$ restarted growth at the maximum value of $2.15 \times 10^{5}$ cells. $\mathrm{mL}^{-1}\left(20^{\text {th }}\right.$ day $)$ in NPK culture medium. Cell concentration was significantly lower in WC medium when compared to that of NPK and $\mathrm{M}+\mathrm{NPK}$ culture media under the same light intensity during the period (9-20 days) (Figure 1).

Maximum and minimum cell counts, $5.4 \times 10^{5}$ cells. $\mathrm{mL}^{-1}$ and $1.26 \times 10^{5}$ cells. $\mathrm{mL}^{-1}$ were obtained in NPK culture medium under light intensity of $60 \mu \mathrm{mol} . \mathrm{m}^{2} \mathrm{~s}^{-1}$. During cultivation, growth increase reached high levels in

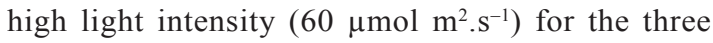
culture media, varying between $2.14 \times 10^{5}$ cells. $\mathrm{mL}^{-1}$

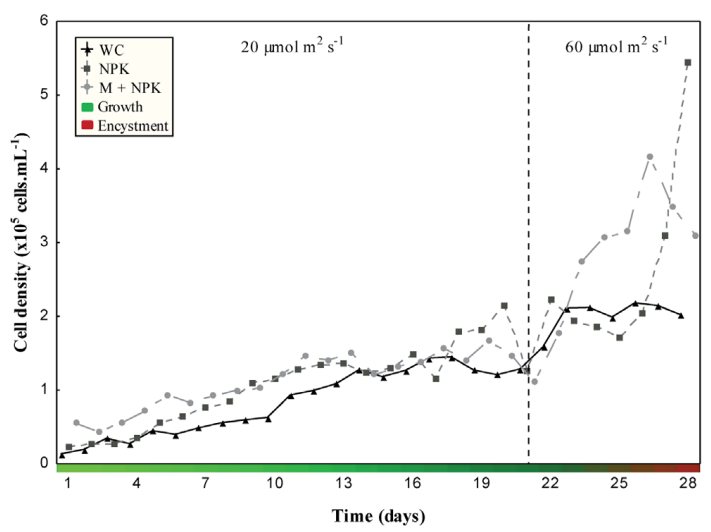

Figure 1. Growth of Haematococcus pluvialis in different media (WC, NPK and M+NPK). 
and $1.28 \times 10^{5}$ cells. $\mathrm{ml}^{-1}$ for WC medium; between $1.78 \times 10^{5}$ cells.mL $\mathrm{m}^{-1}$ and $4.17 \times 10^{5}$ cells. $\mathrm{mL}^{-1}$ for $\mathrm{M}+\mathrm{NPK}$ medium; $1.26 \times 10^{5}$ cells. $\mathrm{mL}^{-1}$ and $5.44 \times 10^{5}$ cells. $\mathrm{mL}^{-1}$ for NPK medium (Figure 1).

The best increase in the growth curve of $H$. pluvialis occurred under environmental stress, such as high light intensities $\left(60 \mu \mathrm{mol} . \mathrm{m}^{2} . \mathrm{s}^{-1}\right), \mathrm{pH}$ above 5.5 and ammonium varying between 0.5 and $2.4 \mathrm{mg} . \mathrm{L}^{-1}$, except in $\mathrm{WC}$ medium (less than $\left.0.04 \mathrm{mg} . \mathrm{L}^{-1}\right)$. Difference $(\mathrm{p}<0.05)$ was reported in the culture medium between parameters, with the exception of temperature, nitrite and DO. Constant air bubbling of medium contained dissolved oxygen content over $7.5 \mathrm{mg} . \mathrm{L}^{-1}$. When light intensity increased in the M+NPK medium, the nutrients decreased, mainly nitrogen compounds. The opposite occurred in the NPK medium with regard to nitrogen compounds. In nitrogen compounds, ammonia was dominant with the highest rates in NPK ( 0.7 to $1.5 \mathrm{mg} . \mathrm{L}^{-1}$ ) and $\mathrm{M}+\mathrm{NPK}\left(0.5\right.$ to $\left.2.4 \mathrm{mg} . \mathrm{L}^{-1}\right)$ media. Total phosphorus was high, over $1.40 \mathrm{mg} . \mathrm{L}^{-1}$, in all media, with highest rates obtained in NPK medium (2.8$\left.3.1 \mathrm{mg} . \mathrm{L}^{-1}\right)$. Similarly, orthophosphate was higher in NPK medium (2.6-2.9 mg. $\left.\mathrm{L}^{-1}\right)$ and lowest in WC (1.5-1.9 mg.. $\left.\mathrm{L}^{-1}\right)$ and M+NPK (1.3-1.8 mg. $\left.\mathrm{L}^{-1}\right)$ media. The conductivity was also highest in NPK medium $\left(>1700 \mu \mathrm{S} . \mathrm{cm}^{-1}\right)$ and significantly different $(\mathrm{p}<0.01)$ among the media. Moreover, $\mathrm{pH}$ was alkaline $(>7)$ in $\mathrm{WC}$ medium and ranged between 4 and 7 in the other media (Table 2; Figure 2).
In the case of green vegetative cells ( $1^{\text {st }}$ to $19^{\text {th }}$ day), constant speed for $H$. pluvialis was $\mathrm{k}=0.16$, with average density $1.2 \times 10^{5}$ cells. $\mathrm{mL}^{-1}$ in $\mathrm{WC}$ medium; $\mathrm{k}=0.13$, with average density $1.8 \times 10^{5}$ cells. $\mathrm{mL}^{-1}$ in NPK medium; $\mathrm{k}=0.05$ with average density $1.6 \times 10^{5}$ cells. $\mathrm{mL}^{-1}$ in $\mathrm{M}+\mathrm{NPK}$ medium. However, when light intensity increased, $\mathrm{k}$ was higher in NPK $(\mathrm{k}=0.22)$ and $\mathrm{M}+\mathrm{NPK}(\mathrm{k}=0.13)$ than in the WC medium $(\mathrm{k}=0.06)$. The opposite was observed with $H$. pluvialis where production time was higher in WC medium (17.2 days) than in the other media in light intensities (Table 3).

During the experimental period, which included the vegetative period and encystment (red pigment), dry weight was similar in WC and NPK medium (860-2500 pg.cell ${ }^{-1}$ ) and slightly lower in M+NPK medium (865-1565 pg.cell ${ }^{-1}$ ). However, cell volume, total length and TOC were higher in WC medium. Chlorophyll- $a$ was significantly higher $(\mathrm{p}<0.05)$ in NPK medium $\left(41-102 \mu \mathrm{g} . \mathrm{L}^{-1}\right)$ and lower in WC and M+NPK (14-61 $\left.\mu \mathrm{g} . \mathrm{L}^{-1}\right)$. The same was observed with regard to astaxanthin content, or rather, it was higher in WC medium $(\mathrm{p}<0.05)$ when compared to NPK and $\mathrm{M}+\mathrm{NPK}$ media during the study period. Ash contents were similar in WC and NPK media and higher in M+NPK medium. The same was observed with regard to doubling time (Table 3).

Protein content ranged between 28 and $48 \%$ of total algal dry matter and lipids were below $10 \%$ of dry matter. Protein contents

Table 2. Estimated parameters of Haematococcus pluvialis cultured in three different media (WC, NPK and M+NPK) in 2-L volume.

\begin{tabular}{lcccc}
\hline \multicolumn{1}{c}{ Parameters } & \multicolumn{3}{c}{ Media } & \multirow{2}{*}{ ANOVA } \\
\cline { 2 - 3 } \multicolumn{1}{c}{ Nitrate $\left(\mathrm{mg} . \mathrm{L}^{-1}\right)$} & $0.6 \pm 0.4$ & $0.3 \pm 0.3$ & $0.6 \pm 0.4$ & $\mathrm{p}<0.01$ \\
Ammonia $\left(\mathrm{mg} . \mathrm{L}^{-1}\right)$ & $0.04 \pm 0.01$ & $1.2 \pm 0.3$ & $1.9 \pm 0.7$ & $\mathrm{p}<0.01$ \\
Nitrite $\left(\mathrm{mg} . \mathrm{L}^{-1}\right)$ & $0.1 \pm 0.1$ & $0.3 \pm 0.2$ & $0.1 \pm 0.07$ & $\mathrm{p}>0.05$ \\
Orthophosphate $\left(\mathrm{mg} . \mathrm{L}^{-1}\right)$ & $1.7 \pm 0.2$ & $2.8 \pm 0.1$ & $1.7 \pm 0.2$ & $\mathrm{p}<0.01$ \\
Total phosphorus $\left(\mathrm{mg} . \mathrm{L}^{-1}\right)$ & $1.8 \pm 0.3$ & $2.9 \pm 0.1$ & $1.9 \pm 0.2$ & $\mathrm{p}<0.01$ \\
pH & $7.9 \pm 1$ & $5.5 \pm 0.9$ & $5.7 \pm 1.5$ & $\mathrm{p}<0.05$ \\
Conductivity $\left(\mu \mathrm{S} . \mathrm{cm}^{-1}\right)$ & $597 \pm 162$ & $1,964 \pm 148$ & $228 \pm 60$ & $\mathrm{p}<0.01$ \\
Dissolved oxygen $\left(\mathrm{mg}^{-1} \mathrm{~L}^{-1}\right)$ & $8.4 \pm 0.6$ & $8.1 \pm 0.3$ & $8.0 \pm 0.8$ & $\mathrm{p}>0.05$ \\
Temperature $\left({ }^{\circ} \mathrm{C}\right)$ & $21 \pm 0.9$ & $21 \pm 1.3$ & $21 \pm 0.9$ & $\mathrm{p}>0.05$ \\
\hline
\end{tabular}

Rates are the average of three replications; variations $( \pm)$ are standard deviations.

Table 3. Summary of some physiological parameters of Haematococcus pluvialis cultured in WC, NPK and M+NPK media in 2-L volume.

\begin{tabular}{|c|c|c|c|c|}
\hline \multirow{2}{*}{ Parameters } & \multicolumn{3}{|c|}{ Media } & \multirow{2}{*}{ ANOVA } \\
\hline & WC & NPK & M+NPK & \\
\hline Cell density $\left(\times 10^{5}\right.$ cell. $\left.\mathrm{mL}^{-1}\right)$ & $1.1 \pm 0.6$ & $1.5 \pm 1$ & $1.6 \pm 0.9$ & $p>0.05$ \\
\hline Growth rate $(\mathrm{k})$ & 0.15 & 0.17 & 0.09 & $\mathrm{p}>0.05$ \\
\hline Doubling time (days) & 6.8 & 5.8 & 11 & $\mathrm{p}>0.05$ \\
\hline Total length $(\mu \mathrm{m})$ & $32 \pm 4.7$ & $25 \pm 5.3$ & $27 \pm 2.6$ & $\mathrm{p}<0.05$ \\
\hline Cell volume $\left(\mu \mathrm{m}^{3}\right)$ & $19,811 \pm 8,500$ & $10,467 \pm 5,330$ & $11,652 \pm 3,860$ & $\mathrm{p}>0.05$ \\
\hline Dry weight (pg.cell ${ }^{-1}$ ) & $1,654 \pm 637$ & $1,660 \pm 820$ & $1,115 \pm 274$ & $\mathrm{p}>0.05$ \\
\hline TOC (pg.cell $\left.{ }^{-1}\right)$ & $3,994 \pm 1,795$ & $2,047 \pm 1,078$ & $2,289 \pm 791$ & $\mathrm{p}>0.05$ \\
\hline Chlorophyll- $a\left(\mathrm{mg} \cdot \mathrm{L}^{-1}\right)$ & $41 \pm 21$ & $66 \pm 25$ & $26 \pm 21$ & $\mathrm{p}<0.05$ \\
\hline Astaxathin (mg.L $\left.\mathrm{L}^{-1}\right)$ & $0.03 \pm 0.02$ & $0.02 \pm 0.01$ & $0.02 \pm 0.005$ & $\mathrm{p}<0.05$ \\
\hline Ash contents ( $\%$ dry weigth) & 1.0 & 1.0 & 1.4 & $\mathrm{p}>0.05$ \\
\hline
\end{tabular}

Rates are the average of three replications; variations $( \pm)$ are standard deviations. 
decreased when light intensities increased $\left(60 \mu \mathrm{mol} \cdot \mathrm{m}^{2} . \mathrm{s}^{-1}\right)$. No difference $(\mathrm{p}>0.05)$ was reported with regard to proteins and lipids between the culture media (Figure 3).

Production cost of $10-\mathrm{L}$ of $H$. pluvialis was low in all media, but WC had a higher cost than the media with fertilizer and macrophyte. NPK and M+NPK media showed a cost reduction of $65 \%$ and $82 \%$, respectively, when compared with commercial medium (Table 4).
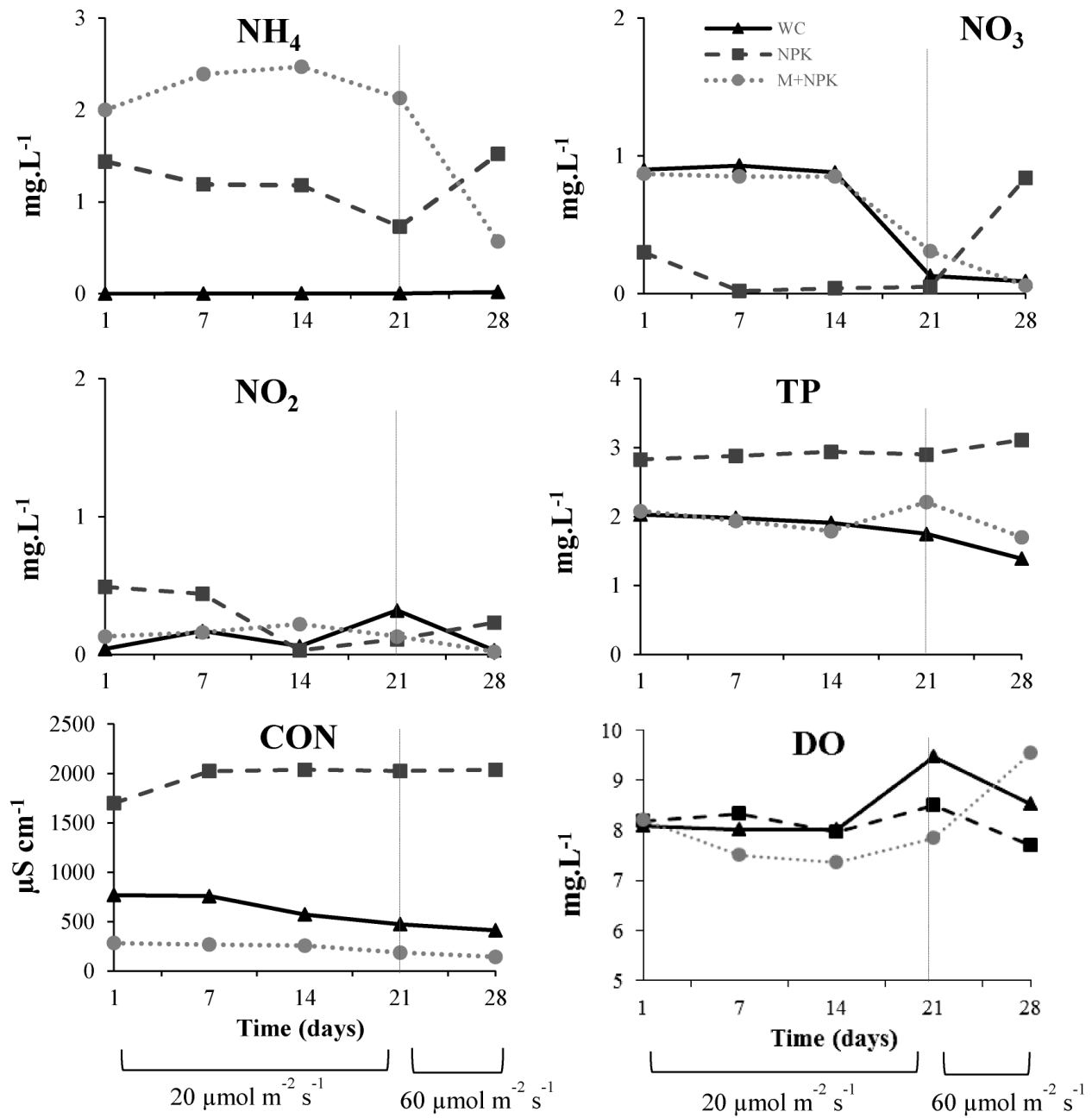

Figure 2. Ammonia $\left(\mathrm{NH}_{4}\right)$, nitrate $\left(\mathrm{NO}_{3}\right)$, nitrite $\left(\mathrm{NO}_{2}\right)$, total phosphorus $(\mathrm{TP})$, conductivity $(\mathrm{CON})$ and dissolved oxygen (DO) contents in three different culture media (WC, NPK and M+NPK) of Haematococcus pluvialis in 2-L volume.
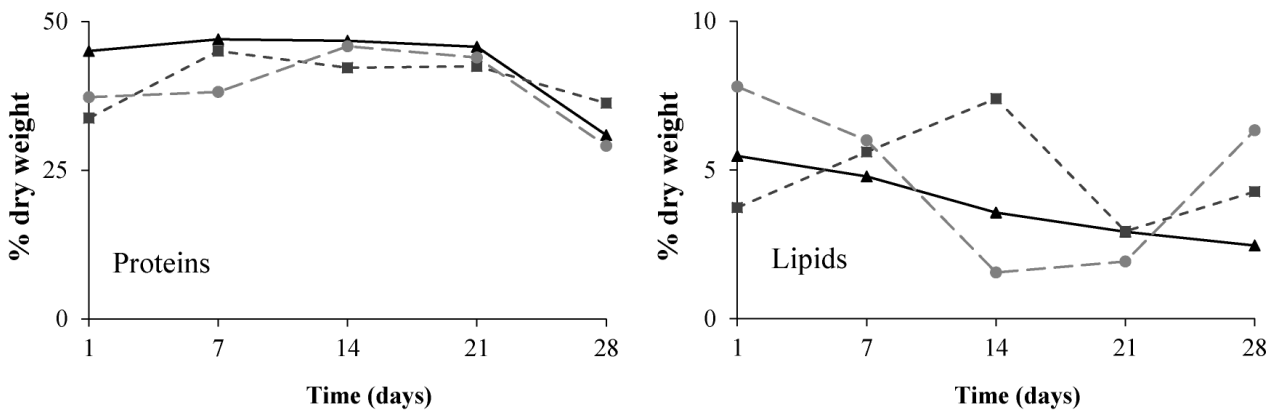

$$
\longrightarrow \mathrm{WC}-\stackrel{\mathrm{n}}{\mathrm{n}-\mathrm{NPK}}-\bullet \mathrm{M}+\mathrm{NPK}
$$

Figure 3. Proteins and lipids (\% dry weight) contents in three different culture media (WC, NPK and M+NPK) of Haematococcus pluvialis in 2-L volume. 
Table 4. Analyses of culture media (WC, NPK and M+NPK) and vitamin B complex prices (in US\$ dollars) ${ }^{\mathrm{a}}$ for $10-\mathrm{L}$ volume of Haematococcus pluvialis.

\begin{tabular}{lc}
\hline \multicolumn{1}{c}{ Culture Media } & Cost (USS / 10-L) \\
\hline WC & 1.31 \\
NPK (20-5-20) & 0.29 \\
M+NPK & 0.36 \\
\hline
\end{tabular}

${ }^{a}$ Average exchange rate (October 2013) US\$1.00 $=\mathrm{R} \$ 2.22$

\section{Discussion}

Two major aspects are usually considered for improvement when developing an optimal process for microalgae products. One aspect deals with the effect of environmental factors such as temperature, light intensity, $\mathrm{pH}$, aeration and agitation; the other refers to the selection of a suitable nutrient medium (Imamoglu et al., 2007).

High cell density in alternative (NPK and M+NPK) and commercial (WC) media was associated to light intensity and nutrients rather than to $\mathrm{pH}$. Most microalgae species are favored by neutral $\mathrm{pH}$. In fact, $H$. pluvialis usually grows well with $\mathrm{pH}$ around 7 and 8 (Zhang et al., 2009). In current study, $\mathrm{pH}$ in WC medium was neutral but it was low in NPK and M+NPK media. Light intensity actually affected cell density. The use of nitrate source (477.5 g.L.-1) in WC medium led to a slightly lower $H$. pluvialis growth rate than in NPK and M+NPK media.

It is well known that the addition of one or more micronutrients is essential for microalgal growth; that the absence of $\mathrm{Mn}$, Co or Fe decreases biomass concentration in the culture by up to $50 \%$; that the effect of depleting several minerals ( $\mathrm{B}, \mathrm{Ca}, \mathrm{Co}, \mathrm{Cu}, \mathrm{Fe}, \mathrm{Mn}, \mathrm{Mo}$ and $\mathrm{Zn}$ ) decreases biomass concentration (Chen et al., 2011). Cell concentrations in M+NPK culture medium were similar or higher than those in WC culture medium due to the great number of nutrients, mainly Fe.

Light intensity might have influenced algal lipid synthesis, with strong illumination inducing their accumulation (Damiani et al., 2010). Low lipids contents observed in this study $(<10 \%$ dry matter) may be associated to high nitrogen contents and low luminosity. In general, nitrogen has a marked positive effect on growth and a negative effect on lipid accumulation, due to the fact that microalgae assimilate several nitrogen sources (ammonium, urea and nitrate). However, nitrogen is an essential element for microalgae's growth development, reproduction and other physiological activities (Wang et al., 2013). Ammonium is not only the most preferred nitrogen source for algae, but also the most energetically efficient source, since less energy is required for its uptake (Tocquin et al., 2012). Current results showed that alternative media (NPK and $\mathrm{M}+\mathrm{NPK}$ ) had high nitrogen and phosphorus contents, indicating that they were good tools when only nutrients were needed.

In current study, protein contents in Haematococcus pluvialis culture amounted to about $30 \%$ and $48 \%$ of dry weight. The higher protein contents observed in microalgae cultured with the commercial medium was associated to high content of total nitrogen in WC $\left(477.5\right.$ g. $\left.\mathrm{L}^{-1}\right)$ when compared to that of NPK and M+NPK $\left(\leq 11\right.$ g.L $\left.\mathrm{L}^{-1}\right)$. Batista et al. (2013) reported that $H$. pluvialis protein contents were low, or rather, around $10.2 \%$ of dry weight; lipids were high, or rather, $40.7 \%$ of dry weight. These results contrasted those in current study.

Carbon rate characterizes algae nutritional rates and constitutes $40-50 \%$ of algal biomass, although biomass is $47-50 \%$ in H. pluvialis (Zhang et al., 2009). Results of organic carbon in current research agreed with the literature. High chlorophyll- $a$ contents in NPK and M+NPK media (> $48 \mathrm{mg} . \mathrm{L}^{-1}$ ) were associated with intrinsic conditions of Chlorophyceae microalgae which contained large amounts of chlorophyll or approximately $45 \%$ of dry weight (Chen et al., 2009).

The efficiency of NPK and M+NPK media cannot be explained by absolute availability of nutrients, since WC medium contained the same amount of nutrients (macro and micro nutrients) or more. NPK and M+NPK media had a specific physiological effect on cell density, chlorophyll- $a$ and ash contents. The higher cell concentration in NPK medium light intensity (20 and $60 \mu \mathrm{mol} . \mathrm{m}^{2} . \mathrm{s}^{-1}$ ) was associated to phosphate (orthophosphate and total phosphorus) in the medium. In fact, current results indicated that high phosphate $\left(2.8 \mathrm{mg} . \mathrm{L}^{-1}\right)$ was the key feature leading to beneficial effects on cell growth. Compared to nitrate, phosphate received less attention in optimization approaches although it promoted growth at moderate and low concentrations (Tocquin et al., 2012).

NPK fertilizer is a low-cost nitrogen fertilizer and a relevant tool in microalgae culture, mainly for Chlorophyceae species. In current study, a great difference in price was found between WC medium and NPK fertilizer, with savings for fertilizer reaching more than $60 \%$. Choice of medium depends on several factors, namely, growth requirements of algae, the manner the medium's constituents may affect the final product, quality and costs (Dalay et al., 2007). Current experiment showed that the best results were obtained with the media NPK and M+NPK at light intensity $60 \mu \mathrm{mol}$. $\mathrm{m}^{2} \cdot \mathrm{s}^{-1}$. Since NPK and M+NPK contain five vitamins and WC culture medium contains two $\left(\mathrm{B}_{6}-\right.$ Biotin and $\mathrm{B}_{1}$ - thiamine), the former are generally more expensive. According to Imamoglu et al. (2007), with regard to vitamins, thiamine was established as a growth factor for $H$. pluvialis, while $\mathrm{B}_{12}$ stimulated growth, albeit not essentially. Several studies report that vitamins are effective for $H$. pluvialis culture. Kaewpintong et al. (2007) reported that the best $\mathrm{B}_{12}$ concentration was $12 \mu \mathrm{g} . \mathrm{L}^{-1}$. Indeed, results of current study, based on vitamin $B_{12}$ complex concentration, was $33 \mu \mathrm{g} . \mathrm{L}^{-1}$, maintained cell density during vegetative stage between $0.1 \times 10^{5}$ cells. $\mathrm{mL}^{-1}$ and $2.1 \times 10^{5}$ cells. $\mathrm{mL}^{-1}$. NPK and M+NPK culture media are more cost saving than WC culture medium in terms of containing the constituents. The literature has not provided any experimental studies on M+NPK culture medium, except Sipaúba-Tavares et al. (2009). 
Medium based on commercial fertilizer and macrophyte (E. crassipes) provided a new formulation that proved to be efficient, at least in batch culture mode, by promoting high density culture of $H$. pluvialis. Since WC medium formulations are usually time consuming and expensive, better experimental design techniques should be implemented to overcome these problems. If $H$. pluvialis has to be maintained in vegetative cell density culture, the NPK (20-5-20) medium is a good tool for this type of culture. Results have demonstrated that levels of physiological parameters, such as cell density, growth rate doubling time, chlorophyll- $a$ and ash contents, were higher in alternative media and that astaxanthin contents were similar among the media. NPK medium and macrophyte (E. crassipes) medium seem to be an adequate alternative to replace the conventional one (WC).

\section{Acknowledgements}

The authors would like to thank the CNPq for awarding a scholarship to the last author (120968/2012-6) and to FAPESP for its financial support (12/09844-4). The authors would also like to thank Dr. Sergio O. Lourenço for kindly providing the $H$. pluvialis strain and to the colleagues of the Limnology and Plankton Production Laboratory for their help in laboratory analyses.

\section{References}

ASSOCIATION OF OFFICIAL ANALYTICAL CHEMISTS AOAC, 1990. Official methods of analysis. 15th ed. Rockville: AOAC.

BATISTA, A.P., GOUVEIA, L., BANDARRA, N.M., FRANCO, J.M. and RAYMUNDO, A., 2013. Comparison of microalgal biomass profiles as novel functional ingredient for food products. Algal Research, vol. 2, no. 2, pp. 164-173. http://dx.doi.org/10.1016/j. algal.2013.01.004

CARVALHO, P.R.N., COLLINS, C.A. and RODRIGUEZ-AMAYA, D.B., 1992. Comparison of pro-vitamin: a determination by normal-phase gravity flow column chromatography and reversed phase high performance liquid chromatography. Chromatographia, vol. 33, no. 2, pp. 133-137. http://dx.doi.org/10.1007/BF02275893.

CHEN, M., TANG, H., MA, H., HOLLAND, T.C., NG, K.Y. and SALLEY, S.O., 2011. Effect of nutrients on growth and lipid accumulation in the green algae Dunaliella tertiolecta. Bioresource Technology, vol. 102, no. 2, pp. 1649-1655. http:// dx.doi.org/10.1016/j.biortech.2010.09.062. PMid:20947341

CHEN, W., ZHANG, C., SONG, L., SOMMERFELD, M. and HU, Q., 2009. A high thought Nile red method for quantitative measurement of neutral lipids in microalgae. Journal of Microbiological Methods, vol. 77, no. 1, pp. 41-47. http://dx.doi. org/10.1016/j.mimet.2009.01.001. PMid:19162091.

DALAY, M.C., IMAMOGLU, E. and DEMIREL, Z., 2007. Agricultural fertilizers as economical alternative for cultivation of Haematococcus pluvialis. Journal of Microbiology and Biotechnology, vol. 17, no. 3, pp. 393-397. PMid:18050940.

DAMIANI, M.C., POPOVICH, C.A., CONSTENLA, D. and LEONARDI, P.I., 2010. Lipid analysis in Haematococcus pluvialis to assess its potential use as a biodiesel feedstock. Bioresource
Technology, vol. 101, no. 11, pp. 3801-3807. http://dx.doi. org/10.1016/j.biortech.2009.12.136. PMid:20117928.

FOWLER, J., COHEN, L. and JAWIS, P., 1998. Practical statistics for field biology. 2nd ed. New York: John Wiley \& Sons. 259 p.

GÖKSAN, T., AK, İ. and KILIÇ, C., 2011. Growth characteristics of the alga Haematococcus pluvialis Flotow as affected by nitrogen source, vitamin, light and aeration. Turkish Journal of Fisheries and Aquatic Sciences, vol. 11, no. 1, pp. 377-383.

GOLTERMAN, H.L., CLYMO, R.S. and OHNSTAD, M.A.M., 1978. Methods for physical and chemical analysis of fresh water. 2nd ed. Oxford: Blackwell Scientific Publication. 213 p. IBP Handbook, no. 8.

GUILLARD, R.R.L., 1973. Division rates. In: J.R. STEIN, ed. Handbook of phycological methods: culture methods and growth measurements. London: Cambridge University Press, pp. 289-311.

GUILLARD, R.R.L. and LORENZEN, C.J., 1972. Yellow-green algae with chlorophyllide. Journal of Phycology, vol. 8, no. 1, pp. 10-14.

HILLEBRAND, H., DÜRSELEN, C.D., KIRSCHTEL, D., POLLINGHER, U. and ZOHARY, T., 1999. Biovolume calculation for pelagic and benthic microalgae. Journal of Phycology, vol. 35, no. 2, pp. 403-424. http://dx.doi.org/10.1046/j.15298817.1999.3520403.x

HOFF, F.H. and SNELL, T., 1997. Plankton culture manual. 4th ed. Florida: Florida Aqua Frams Inc. 141 p.

IMAMOGLU, E., VARDAR-SUKAN, F. and DALAY, M.C., 2007. Effect of different culture media and light intensities on growth of Haematococcus pluvialis. International Journal of Natural and Engineering Sciences, vol. 1, no. 3, pp. 5-9.

KAEWPINTONG, K., SHOTIPRUK, A., POWTONGSOOK, S. and PAVASANT, P., 2007. Photoautotrophic high-density cultivation of vegetative cells of Haematococcus pluvialis in airlift bioreactor. Bioresource Technology, vol. 98, no. 2, pp. 288-295. http://dx.doi.org/10.1016/j.biortech.2006.01.011. PMid:16516464.

KOROLEFF, F., 1976. Determination of ammonia. In: E. GRASHOFF and E. KREMLING, eds. Methods of seawater analysis. German: Verlag Chemie Weinhein, pp. 126-133.

NUSCH, E.A., 1980. Comparison of different methods for chlorophyll and phaeopigments determination. Archiv für Hydrobiologie, vol. 14, pp. 4-36.

PEREZ-GARCIA, O., ESCALANTE, F.M.E., DE-BASHAN, L.E. and BASHAN, Y., 2011. Heterotrophic cultures of microalgae: metabolism and potential products. Water Research, vol. 45, no. 1, pp. 11-36. http://dx.doi.org/10.1016/j.watres.2010.08.037. PMid:20970155.

ROCHA, O. and DUNCAN, A., 1985. The relationship between cell carbon and cell volume in freshwater algae species used in zooplankton studies. Journal of Plankton Research, vol. 7, no. 2, pp. 279-294. http://dx.doi.org/10.1093/plankt/7.2.279.

SIPAÚBA-TAVARES, L.H. and PEREIRA, A.M.L., 2008. Large scale laboratory cultures of Ankistrodesmus gracilis (Reisch) Korsikov (Chlorophyta) and Diaphanosoma biergei Korinek, 1981 (Cladocera). Brazilian Journal of Biology = Revista Brasileira de Biologia, vol. 68, no. 4, pp. 875-883. http://dx.doi.org/10.1590/ S1519-69842008000400025. PMid:19197508.

SIPAÚBA-TAVARES, L.H. and ROCHA, O., 1993. Upscale culture of planktonic organisms for feeding larvae and fish fry: I- Chlorophyceae. Biotemas, vol. 6, no. 1, pp. 93-106. 
SIPAÚBA-TAVARES, L.H., IBARRA, L.C. and FIORESI, T.B., 2009. Ankistrodesmus gracilis (Reisch) Korsikov (Chlorophyta) laboratory cultured in $\mathrm{CHU}_{12}$ and macrophyte with NPK media. Boletim do Instituto de Pesca, vol. 35, no. 1, pp. 111-118.

STATSOFT INC., 2007 [accessed 09 September 2013]. Statistica: data analysis software system, version 8 [software]. Available from: www.statsoft.com.

TEW, K.S., CONROY, J.D. and CULVER, D.A., 2006. Effects of lowered inorganic phosphorus fertilization rates on pond production of perch fingerlings. Aquaculture, vol. 255, no. 1-4, pp. 436-444. http://dx.doi.org/10.1016/j.aquaculture.2006.01.003.

TOCQUIN, P., FRATAMICO, A. and FRANCK, F., 2012. Screening for a low-cost Haematococcus pluvialis medium reveals an unexpected impact of a low N/P ratio on vegetative growth.
Journal of Applied Phycology, vol. 24, no. 3, pp. 365-373. http:// dx.doi.org/10.1007/s10811-011-9771-3.

VOLLENWEIDER, R.A., 1974. A manual on methods for measuring primary production in aquatic environments. 2nd ed. Oxford: Blackwell Scientific Publications. 225 p. IBP Handbook, no. 12.

WANG, J., HAN, D., SOMMERFELD, M.R., LU, C. and HU, Q., 2013. Effect of initial biomass density on growth and astaxanthin production of Haematococcus pluvialis in an outdoor photo bioreactor. Journal of Applied Phycology, vol. 25, no. 1, pp. 253260. http://dx.doi.org/10.1007/s10811-012-9859-4.

ZHANG, B.Y., GENG, Y.H., LI, Z.K., HU, H.J. and LI, Y.G., 2009. Production of astaxanthin from Haematococcus in open pond by two-stage growth one-step process. Aquaculture, vol. 295, no. 3-4, pp. 275-281. http://dx.doi.org/10.1016/j.aquaculture.2009.06.043. 